\title{
Effects of Board Diversity on Financial Performance of Firms in Malaysia: A Moderating Role of Corporate Sustainability Practices
}

\author{
Mohammad Shahansha Molla* \\ PhD Candidate, School of Economics, Finance and Banking, Universiti Utara Malaysia, Malaysia \\ Yusnidah Ibrahim \\ Professor, School of Economics, Finance and Banking, Universiti Utara Malaysia, Malaysia \\ Zuaini Ishak \\ Associate Professor, Tunku Puteri Intan Safinaz School of Accountancy, Universiti Utara Malaysia, Malaysia
}

\begin{abstract}
The volatile financial performance (FP) of listed firms in Bursa Malaysia has been observed since 2008. The total earnings by companies in FTSE Bursa Malaysia KLCI index in 2016 dropped by 30 percent showing unusual performance pattern among the listed firms. Both FTSE Bursa Malaysia KLCI and EMAS index year on year capital return performance also found negative from 2014 to 2016. The declining FP of firms often associated with weak corporate governance (CG) practices. The board diversity (BD) under CG mechanisms induces the improvement of FP and long-term success of a firm. Since BD impacts on FP, this study proposes a conceptual framework by introducing corporate sustainability practices (CSP) to see how it intervene as a moderator between BD and FP. The conceptual framework offers useful information which may help for further investigating in BD and FP. The future studies should validate empirically the proposed research framework.
\end{abstract}

Keywords: Corporate Sustainability Practices, Board Diversity, Financial Performance, Stakeholder Theory, Bursa Malaysia.

DOI: $10.7176 / \mathrm{JESD} / 10-9-05$

Publication date:May $31^{\text {st }} 2019$

\section{Introduction}

The global economic and financial crises have diminished the public trust in the institutions, principles and the very concept of market economy (Lins, Servaes, \& Tamayo, 2017). Financial scandals and crises often originate from lack of effective corporate governance practices in the corporations (Berger, Imbierowicz, \& Rauch, 2016; Kato, Li, \& Skinner, 2017). It has been considered the most critical issue in business world after global financial crisis as it has shaken many economies and led them to recession. It has also received much attention to the policy makers due to the scandals of giant corporations in the world, such as Adelphia, Xerox, Enron, Parmalat, and Worldcom. Till now, the regulatory bodies and policy makers are trying to resolve the corporate governance issues globally (Hassan, Marimuthu, \& Johl, 2015; Saggar \& Singh, 2017).

During the wave of Asian financial crises in 1997 and in 2008 the activities of the corporate sectors affect entire economy. Financial crises are mainly attributed to the poor corporate governance practices(Kato et al., 2017; Laallam, Alom, \& Mohamad, 2017). Dias et al. (2016) reveal that during the crises, FP of firms usually deteriorates. FP of a firm is extensively recognized as an indicator of management performance. It reflects the managements' effectiveness and efficiency in utilization of resources of a firm (Miles \& Van Clieaf, 2017). Thus, firms are mostly concerned with their financial performance to ensure their long term survival (Odalo, Achoki, \& Njuguna, 2016). Moreover, strong FP of a firm gives a greater ability to undertake higher financial risk in capital budgeting (GómezBezares, Przychodzen, \& Przychodzen, 2017).

The economy of Malaysian is seriously affected in 1997 and 2008 and some key enterprises are forced to close such as Renong Berhad in 2000, United Engineers (Malaysia) Berhad in 2001 and Transmile Group Berhad in 2007. Lack of proper practices of corporate governance is diagnosed as the cause of corporate failure (Hassan et al., 2015). In addition, Laallam et al. (2017) identify weak corporate governance practices are responsible for lower FP of firms in Malaysia. The current market scenario also shows that the FP of listed firms in Bursa Malaysia is more volatile and declining. Table 1 and 2 illustrate the recent performance of firms listed in Bursa Malaysia. 
Table 1 Total net earnings of the companies FTSE Bursa Malaysia KLCI index

\begin{tabular}{|l|l|l|l|l|l|l|}
\hline \multicolumn{1}{|c|}{ Year } & 2011 & 2012 & 2013 & 2014 & 2015 & 2016 \\
\hline Total MYR (in millions) & 51,400 & 57,780 & 59,041 & 60,562 & 56,558 & 54,899 \\
\hline Growth rate & - & $12.4 \%$ & $2.2 \%$ & $2.6 \%$ & $-6.6 \%$ & $-2.9 \%$ \\
\hline Average exchange rate (MYR/USD) & 3.10 & 3.10 & 3.15 & 3.30 & 4.00 & 4.15 \\
\hline Total USD (in millions) & 16,581 & 18,639 & 18,743 & 18,352 & 14,140 & 13,229 \\
\hline Growth rate & - & $12.4 \%$ & $0.6 \%$ & $-2.1 \%$ & $-23.0 \%$ & $-6.4 \%$ \\
\hline
\end{tabular}

Source: ("Corporate Governance in Malaysia," 2017)

Table 2 Year on year capital return performance of FTSE Bursa Malaysia KLCI and EMAS index

\begin{tabular}{|l|l|l|l|l|l|l|}
\hline Index & 2011 & 2012 & 2013 & 2014 & 2015 & 2016 \\
\hline FTSE Bursa Malaysia KLCI & $0.8 \%$ & $10.3 \%$ & $10.5 \%$ & $-5.7 \%$ & $-3.9 \%$ & $-3.0 \%$ \\
\hline FTSE Bursa Malaysia EMAS & $1.1 \%$ & $9.0 \%$ & $12.4 \%$ & $-6.1 \%$ & $-2.3 \%$ & $-2.8 \%$ \\
\hline
\end{tabular}

Source: (FTSE Russel, 2017)

From the above tables, it is observed that financial performance of firms listed in Bursa Malaysia has improved after 2008 financial crises until 2014 but in 2015 and 2016 the performance of firms is again declining. It is also observed that the total earnings by companies in FTSE Bursa Malaysia KLCI index in 2016 is worse than 2012. In terms of US dollar which is one of the significant considerations of international investors is also much worse. From 2012 to 2014 the combined profit is approximately USD 18.5 million, while it is roughly $30 \%$ below that level in 2016. Not only that, both FTSE Bursa Malaysia KLCI and EMAS index year on year capital return performance are observed to be negative from 2014 to 2016.

Due to financial scandals and shut down of companies over the previous couple of years, as well as financial crisis of 2008, it has much concerns for improving board effectiveness in the corporate sectors globally (RegueraAlvarado, de Fuentes, \& Laffarga, 2017). Diversified person in the board has been considered as an effective approach to increase such effectiveness (K1lıç \& Kuzey, 2016). Board diversity refers to the difference in behavior, qualities and other characteristics among individuals and groups in the board (Abdullah, 2014; Gordini \& Rancati, 2017). Presently, all the corporations in the world are encouraged to diversify their board of directors (BOD). Because, the decisions of the BOD and their lack of diversity are considered responsible for recent corporate scandals of Dynegy, Glitnir and Lehman Brothers (Terjesen, Couto, \& Francisco, 2016). A good number of researchers have examined the association between BD and firms' FP but the results are not conclusive till date (Terjesen et al., 2016).

Moreover, there is an ambiguity in the previous researches regarding diversity issue at board level and FP of firm (Hassan et al., 2015). A mentionable number of studies concerning BD and FP of firms reported an insignificant direct relationship between the two (Galbreath, 2016). In fact, little is known about why and when the BD would influence FP (Roberson, Holmes, \& Perry, 2016). So, it is plausible to carry out further study on the link between BD and FP issue in a more holistic way (Hassan et al., 2015). Additionally, Umans (2013) and Roberson et al. (2016) argue that as the relationship between the two variables have reported mixed results, the concerned parties could be benefitted from the investigation of critical influences of any third interaction variables on that relationship.

For investigating the role of any third interaction variable on the above relationship, this article aims to use CSP as a moderator between them because CSP of the firm has also an influence on its FP (Lins et al., 2017; Rivera, Muñoz, \& Moneva, 2017). CSP is a widespread management idea that assures long term financial success and survival of a firm (Lopatta, Buchholz, \& Kaspereit, 2016; Molla, Ibrahim, \& Ishak, 2019; Zahid \& Ghazali, 2015). CSP refers to the using of resources for living and working at present that fulfill and incorporate present economic, environmental and social necessities by not spoiling the needs of next generations (Ong, Soh, Teh, \& $\mathrm{Ng}, 2016)$. Li, Fu, and Huang (2015) investigate the moderation effects of CSP on the association between decoration style and consumers' purchase intention in Chinese perspective and found a significant interaction effect of CSP. However, using of CSP as a moderator between BD and FP has not been given enough attention by the researchers so far. Research in the areas of BD and sustainability is often treated separately with less attention paid to the interaction of both areas (Fernández-Gago, Cabeza-García, \& Nieto, 2016). This study extends pioneering attempt by examining the moderating effects of CSP on BD and FP of firms in Malaysia.

\section{Research Approach}

This article broadly reviews the past literature related to $\mathrm{BD}, \mathrm{CSP}$, and $\mathrm{FP}$ of firms. The relevant journals, international conference papers, and book chapters have been selected which are published mainly by different globally recognized publishers like Springer, Elsevier, Taylor \& Francis, Emerald, Wiley Online Library, Sage, etc. 


\section{Conceptual Research Framework}

There are two ways BD might influence firms' FP. Firstly, BD directly influences the firms' FP which is based on the agency theory and the resource dependence theory and empirical evidence from previous studies. Secondly, BD can influence FP of firms with the help of CSP which is based on the stakeholder theory. Figure 1 shows the conceptual research framework of the paper.

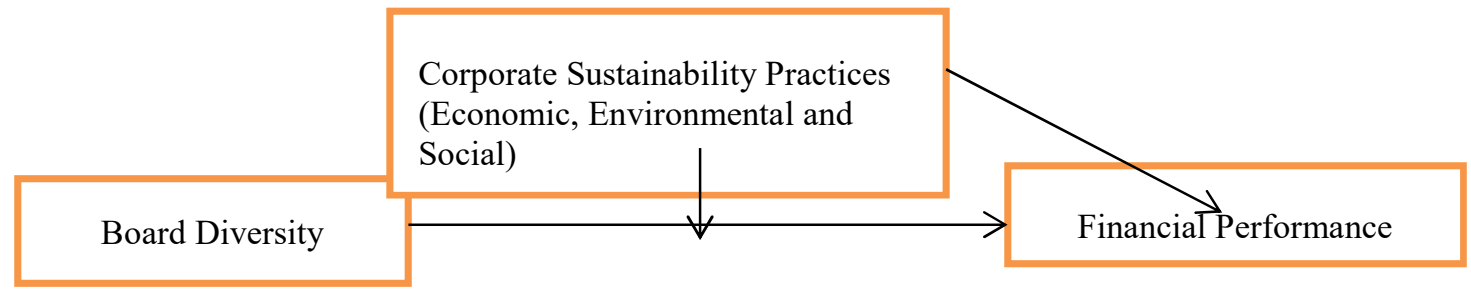

Figure 1: Conceptual Research Framework

\section{Arguments for Using CSP as a Moderating Variable}

The term sustainability has become widely accepted after the definition given by Harlem Brundtland, former prime minister of Norway, who defines sustainable development as "meeting the needs of the present without compromising the ability of future generations to meet their own needs"(World Commission on Environment and Development, 1987, p. 43). According to the Commission of the European Communities (2001) CSP refers to the ability of a corporation to contribute in the economic, environmental and social development. Elkington (1999) has mentioned it as a triple bottom line (TBL). The main objective of TBL is not to please the shareholders only, like the agency theory (Jensen \& Meckling, 1976) but also to consider the other stakeholders' interests (Freeman, Harrison, Wicks, Parmar, \& De Colle, 2010). Lins et al. (2017) find that during the financial crisis in 2008, firms with high CSP earned $4 \%$ to $7 \%$ higher stock returns than the firms who had low CSP. Higher CSP firms also earned higher rate of profit, higher growth rate and increased sales comparatively to the firms who had lower CSP. These findings recommend that higher level of investment in CSP brings higher level of FP and trust of stakeholders on the firm.

The level to which BD can positively influence FP of firms depends on the extent to which boards are motivated to disseminate the diverse knowledge, experience, and values of their members (Post \& Byron, 2015). It is found from the social psychology research that diverse groups vary in their ability to stimulate and systematically process their diverse knowledge and values of individual member (Stasser \& Titus, 2003). Haleblian and Finkelstein (1993) find that characteristics of a firm's environment moderate the relationship between top level management and firm performance. Post and Byron (2015) find shareholder protections positively moderate the relationship between $\mathrm{BD}$ and FP of firms. They also reveal that robust shareholder protections increases the strength of corporate governance practices while lower protections weaken the governance mechanism that is same as the findings of Porta, Lopez de Silanes, and Shleifer (1999) research. It indicates that when a firm has less shareholder protections the BOD is less motivated to optimize their decisions because directors do not want to be liable for failures of fiduciary responsibilities (Post \& Byron, 2015).

Extending the above work, this paper argues that the economic, environmental and social activities of firms moderate the relationship between BD and FP of firms. In particular, the degree of sustainability activities determines how BD influences FP. Specifically, this article argues that CSP of a firm can attract and retain diversified skilled and talented directors (Baron, 2008). The combination of different talented people in the BOD of an organization can help to increase more its FP and achieve sustainable competitive advantage. This paper expects that the relationship between diverse boards and FP of firm to be more positive with stronger sustainability practices because such practices motivate boards to improve their decision making. Therefore, this study assumes that the extent to which a firm with more CSP will positively moderate the relationship between BD and FP of firms.

\section{Conclusion}

As an emerging economy, Malaysia has much developed its capital market after 2008 financial crises until 2014 but in 2015 the performance of firms is again declining that is alarming and destructive for economic development. Among the different factors, weak corporate governance practices are caused for decreasing the financial performance of firms. In this connection, less diversity in the board of directors is found in the listed firms in Malaysia. However, the relationship between BD and FP cannot be generalized as the results are found mixed till now. A good number of researchers perceive a black box in the connection between the variables. Some researchers suggested for examining the interaction effect of any third variable on this association to determine the exact relationship. To solve this dilemma, based on the stakeholder theory and previous literatures, this article assumes CSP might moderate the relationship between BD and FP of firms in Malaysia. This paper is prepared on the basis 
of literature review and some widely accepted theories that are frequently used in corporate governance and sustainability issues. It is suggested to justify the research framework empirically by further study.

\section{References}

Abdullah, S. N. (2014). The causes of gender diversity in Malaysian large firms. Journal of Management \& Governance, 18(4), 1137-1159.

Baron, D. P. (2008). Managerial contracting and corporate social responsibility. Journal of Public Economics, 92(1), 268-288.

Berger, A. N., Imbierowicz, B., \& Rauch, C. (2016). The roles of corporate governance in bank failures during the recent financial crisis. Journal of Money, Credit and Banking, 48(4), 729-770.

Commission of the European Communities. (2001). Consultation paper for the preparation of a European Union strategy for sustainable development. Retrieved April 10, 2016, from http://ec.europa.eu/environment/eussd/pdf/ consultation_paper_en.pdf.

Corporate Governance in Malaysia. (2017). $\quad \bar{R}$ etrieved April 22, 2017 from http://cgmalaysia.blogspot.my/2017/03/poor-earnings-growth-for-bursa-listed.html

Dias, A., Dias, A., Rodrigues, L. L., Rodrigues, L. L., Craig, R., \& Craig, R. (2016). Global financial crisis and corporate social responsibility disclosure. Social Responsibility Journal, 12(4), 654-671.

Elkington, J. (1999). Triple bottom line revolution: reporting for the third millennium. Australian CPA, 69(11), $75-$ 76.

Fernández-Gago, R., Cabeza-García, L., \& Nieto, M. (2016). Corporate social responsibility, board of directors, and firm performance: An analysis of their relationships. Review of Managerial Science, 10(1), 85-104.

Freeman, R. E., Harrison, J. S., Wicks, A. C., Parmar, B. L., \& De Colle, S. (2010). Stakeholder theory: The state of the art. New York: Cambridge University Press.

FTSE Russel. (2017). FTSE Bursa Malaysia KLCI Retrieved April 22, 2017 http://www.ftse.com/Analytics/FactSheets/temp/deca55f5-9a54-4531-8001-6da62e87e806.pdf

Galbreath, J. (2016). Is board gender diversity linked to financial performance? The mediating mechanism of CSR. Business \& Society. doi: 10.1177/0007650316647967

Gómez-Bezares, F., Przychodzen, W., \& Przychodzen, J. (2017). Bridging the gap: How sustainable development can help companies create shareholder value and improve financial performance. Business Ethics: A European Review, 26(1), 1-17.

Gordini, N., \& Rancati, E. (2017). Gender diversity in the Italian boardroom and firm financial performance. Management Research Review, 40(1), 75-94.

Haleblian, J., \& Finkelstein, S. (1993). Top management team size, CEO dominance, and firm performance: The moderating roles of environmental turbulence and discretion. Academy of Management Journal, 36(4), 844863.

Hassan, R., Marimuthu, M., \& Johl, S. K. (2015). Diversity, corporate governance and implication on firm financial performance. Global Business and Management Research, 7(2), 28-36.

Jensen, M. C., \& Meckling, W. H. (1976). Theory of the firm: Managerial behavior, agency costs and ownership structure. Journal of Financial Economics, 3(4), 305-360.

Kato, K., Li, M., \& Skinner, D. J. (2017). Is Japan really a "buy"? The corporate governance, cash holdings and economic performance of japanese companies. Journal of Business Finance \& Accounting, 44(3-4), 480-523.

Kılıç, M., \& Kuzey, C. (2016). The effect of board gender diversity on firm performance: Evidence from Turkey. Gender in Management: An International Journal, 31(7), 434-455.

Laallam, A., Alom, F., \& Mohamad, A. (2017). The effects of corporate governance attributes and code amendments on the performance of Malaysian trading and services firms. International Journal of Economics and Business Research, 13(1), 72-94.

Li, Y., Fu, H., \& Huang, S. S. (2015). Does conspicuous decoration style influence customer's intention to purchase? The moderating effect of CSR practices. International Journal of Hospitality Management, 51, 19-29.

Lins, K. V., Servaes, H., \& Tamayo, A. (2017). Social capital, trust, and firm performance: The value of corporate social responsibility during the financial crisis. The Journal of Finance, 72(4), 1785-1824.

Lopatta, K., Buchholz, F., \& Kaspereit, T. (2016). Asymmetric information and corporate social responsibility. Business \& Society, 55(3), 458-488.

Miles, S. J., \& Van Clieaf, M. (2017). Strategic fit: Key to growing enterprise value through organizational capital. Business Horizons, 60(1), 55-65.

Molla, M. S., Ibrahim, Y., \& Ishak, Z. (2019). Corporate sustainability practices: A review on the measurements, relevant problems and a proposition. Global Journal of Management and Business Research, 19(1), 1-8.

Odalo, S. K., Achoki, G., \& Njuguna, A. (2016). Relating company size and financial performance in agricultural firms listed in the nairobi securities exchange in Kenya. International Journal of Economics and Finance, $8(9), 34-40$ 
Ong, T. S., Soh, W. N., Teh, B. H., \& Ng, S. H. (2016). Influence of environmental disclosures on the financial performance of public listed Malaysian manufacturing companies. Asia-Pacific Management Accounting Journal, 10(1), 107-136.

Porta, R., Lopez de Silanes, F., \& Shleifer, A. (1999). Corporate ownership around the world. The Journal of Finance, 54(2), 471-517.

Post, C., \& Byron, K. (2015). Women on boards and firm financial performance: A meta-analysis. Academy of Management Journal, 58(5), 1546-1571.

Reguera-Alvarado, N., de Fuentes, P., \& Laffarga, J. (2017). Does board gender diversity influence financial performance? Evidence from Spain. Journal of Business Ethics, 141(2), 337-350.

Rivera, J. M., Muñoz, M. J., \& Moneva, J. M. (2017). Revisiting the relationship between corporate stakeholder commitment and social and financial performance. Sustainable Development, 25(6), 482-494.

Roberson, Q., Holmes, O., \& Perry, J. (2016). Transforming research on diversity and firm performance: A dynamic capabilities perspective. Academy of Management Annals. doi: 10.5465/annals.2014.0019

Saggar, R., \& Singh, B. (2017). Corporate governance and risk reporting: Indian evidence. Managerial Auditing Journal, 32(4/5), 378-405.

Stasser, G., \& Titus, W. (2003). Hidden profiles: A brief history. Psychological Inquiry, 14(3-4), 304-313.

Terjesen, S., Couto, E. B., \& Francisco, P. M. (2016). Does the presence of independent and female directors impact firm performance? A multi-country study of board diversity. Journal of Management \& Governance, 20(3), 447-483.

Umans, T. (2013). Top management team's cultural diversity and firm performance: The mediating role of ambidextrous orientation. Corporate Ownership \& Control, 11(1), 882-891.

World Commission on Environment and Development. (1987). Our common future. London: Oxford.

Zahid, M., \& Ghazali, Z. (2015). Corporate sustainability practices among Malaysian REITs and property listed companies. World Journal of Science, Technology and Sustainable Development, 12(2), 100-118. 